\title{
Hodgkin's Lymphoma and
} Paraneoplastic Phenomena in the Central Nervous System: A Case Report and Review of the Literature

\author{
Marcus Vetter ${ }^{\mathrm{a}} \quad$ Alexandar Tzankov $^{\mathrm{b}} \quad$ Andreas Engert $^{\mathrm{d}}$ \\ Matthias Mehling ${ }^{c}$ Richard Herrmann ${ }^{a}$ \\ Christoph Rochlitz ${ }^{\mathrm{a}}$
}

aDepartment of Medical Oncology, ${ }^{b}$ Institute of Pathology, and 'Department of Neurology, University Hospital Basel, Basel, Switzerland; ${ }^{d}$ German Hodgkin Study Group, University Hospital, Cologne, Germany

\section{Key Words}

Hodgkin's lymphoma · Central nervous system · Paraneoplastic vasculitis

\begin{abstract}
A 25-year-old male patient presented to our Ear, Nose and Throat clinic with a history of nausea, vomiting, headache, vertigo and weight loss of $5 \mathrm{~kg}$ over the preceding 3 months. An enlarged cervical lymph node was detected at clinical examination. Lymph node biopsy showed nodular lymphocyte-predominant Hodgkin's lymphoma (NLPHL, nodular paragranuloma). Because of the neurological symptoms a cerebral MRI scan was performed and revealed an intense perivascular, bilateral, contrast-medium enhancing lesion of the temporal lobes suggestive of cerebral vasculitis. Cerebrospinal fluid analysis showed an increased number of mononuclear cells, but there was no indication for neurotropic viral or bacterial infections. EEG revealed a left temporal epileptic focus, and anti-epileptic therapy was initiated. NLPHL was treated with 2 cycles of ABVD chemotherapy and $20 \mathrm{~Gy}$ involved-field radiotherapy. Steroid therapy (prednisone 100 $\mathrm{mg}$ q.d.) for the presumed paraneoplastic neurological manifestation was started 1 week before chemotherapy and led to the rapid disappearance of complaints. Because of renewed onset of nausea and vertigo after 3 weeks of treatment with ABVD chemotherapy and 4 weeks of treatment with steroids, a follow-up brain MRI and EEG were performed and demonstrated complete disappearance of the 'vasculitic' changes without additional pathologic findings. Five months after therapy, the patient is without neurological symptoms and a PET-CT showed a complete remission. This case is a unique example of paraneoplastic central nervous system (CNS) involvement in a patient with
\end{abstract}


newly diagnosed NLPHL. We present a review of the literature on paraneoplastic CNS symptoms in Hodgkin's lymphoma.

\section{Background}

Direct central nervous system (CNS) involvement in Hodgkin's lymphoma is extremely rare with an incidence of approximately $0.02 \%$ [1], though primary manifestations of Hodgkin's lymphoma in meninges [2], cerebral fluid [3] or the brain parenchyma [4] are known. Cerebral involvement as CNS-Hodgkin's lymphoma is described in patients with former chronic lymphatic leukemia as a Richter transformation [5].

CNS manifestations, such as paraneoplastic cerebellar degeneration (PCD) in the presence of antibodies (i.e. anti-Tr or anti-mGluR1) against antigens in Purkinje cells, are well known paraneoplastic manifestations of lymphomas [6, 7]. Suggested therapies are steroids, intravenous immunoglobulin and plasmapheresis [6]. Clinical outcomes differ but are usually poor with permanent neurological sequel.

Further, autoimmune disorders such as vasculitis, in particular granulomatous angiitis, have been described as complications in patients with Hodgkin's lymphoma. Small and middle-sized vessels of the brain can be affected in the CNS; this was first described in 1957 by Reich [8]. In Hodgkin's lymphoma, a case series containing histology and clinical course of 10 patients has been published [9].

\section{Case Presentation}

A 25-year-old male patient presented to our Ear, Nose and Throat clinic complaining of nausea lasting for 3 months, vertigo, headache and weight loss of $5 \mathrm{~kg}$ due to repetitive vomiting. Further examination demonstrated an enlarged cervical lymph node on level V. Extirpation of the node was performed and histology showed nodular lymphocyte-predominant Hodgkin's lymphoma (NLPHL, nodular paragranuloma) (fig. 1a-d). Further examination with PET (fig. 2), and bone marrow aspiration and biopsy defined stage II disease.

Because of the neurological symptoms (nausea, vertigo and headache) cerebral MRI was performed and demonstrated intense perivascular, bilateral infiltration of the temporal lobes suspicious of vasculitis (fig. 3). Cerebrospinal fluid (CSF) analysis showed an increased number of mononuclear cells, but there was no indication for neurotropic viral or bacterial infections. CSF cytology and immunophenotyping demonstrated no abnormal neoplastic findings. Specific onconeural antibodies (anti-Hu, anti-Yo, anti-Ri, anti-CV2, anti-amphiphysin, anti-Ma1, anti-Ma2/Ta, anti-Tr) were negative. EEG suggested a left temporal epileptic focus. Anti-epileptic therapy with levetiracetam and lamotrigine was started. For therapy of suspected cerebral vasculitis, steroid therapy was initiated with $100 \mathrm{mg}$ prednisone q.d., with tapering of the dose by $50 \%$ every 5 days. The patient was discharged from the hospital and outpatient chemotherapy with 2 cycles of ABVD (adriamycin, bleomycin, vinblastine and dacarabazine) was started. Within the second cycle of chemotherapy the patient developed a bleomycin pneumopathy and bleomycin was therefore omitted from further treatment. After termination of 2 cycles of chemotherapy, involved-field radiotherapy with $20 \mathrm{~Gy}$ followed.

Because of renewed onset of nausea and vertigo after 3 weeks of treatment with ABVD and 4 weeks of treatment with steroids, a follow-up brain MRI was performed and demonstrated complete disappearance of the 'vasculitic' changes and no other pathologic findings. EEG was also normal. Five months after diagnosis and end of chemotherapy, the patient is in good health without any complaints 
of nausea, emesis, vertigo or headache. Clinically and on PET-CT, there is no evidence of enlarged lymph nodes or metabolically active lymphoma.

The patient has given his written informed consent for the case report to be published.

\section{Discussion}

Direct involvement of the CNS in Hodgkin's lymphoma is rare, with an incidence of about $0.02 \%$, and to our knowledge has never been described in NLPHL [1]. However, various paraneoplastic events in the nervous system, in particular the CNS, have been described in Hodgkin's lymphoma patients and are summarized in table 1. Granulomatous angiitis and PCD are mainly reported in Hodgkin's lymphoma as paraneoplastic events [9]. However, every other part of the nervous system can also be affected by paraneoplastic antibodies. Guillain-Barré syndrome and subacute polyradiculopathy have been reported in Hodgkin's lymphoma and observed after allogeneic stem cell transplantation [10]. Denny-Brown syndrome (paraneoplastic subacute sensory neuropathy) is not common in Hodgkin's lymphomas but mainly described in small cell lung cancer. It is associated with anti-Hu antibodies and is characterized by a severe inflammatory loss of the dorsal roots ganglia [11]. In a patient with thymic Hodgkin's lymphoma, myasthenia gravis due to anti-AChR antibodies was described [12]. After successful treatment, remission of myasthenia occurred as well. Other antibodies against neural structures have been described in several case reports. To et al. [13] have found a $65 \mathrm{kD}$ antibody against retinal protein that caused night blindness in a 24-year-old woman 1 week after initiation of chemotherapy for Hodgkin's lymphoma.

Our patient had an unclear neurological syndrome with presumed vasculitis on cerebral MRI. The differential diagnosis included PDC typically presenting with dizziness, nausea and vomiting, usually with acute onset and followed several days later by gait instability, oscillopsia, diplopia, ataxia, dysarthria and dysphagia [6,7]. Possible causes of PDC are circulating anti-Tr and anti-mGluR1 antibodies destroying Purkinje cells in the cerebellum and leading to severe symptoms in particular ataxia [6, 7]. Our patient had several of these symptoms such as nausea, vomiting and vertigo, but no focal loss of neurological function was found on clinical examination. Patients with PDC typically present with a severe ataxia and cerebellar signs. We found neither pathologic Unterberg's stepping test nor dysdiadochokinesia, other typical clinical signs of PDC, and laboratory testing further excluded this differential diagnosis since PCD-causing anti-Tr antibodies could not be found in serum or CSF, neither at diagnosis nor after treatment. Finally, MRI of our patient did not demonstrate any degeneration in the cerebellum.

However, cerebral MRI showed perivascular bilateral infiltration of the temporal lobes consistent with vasculitis changes, presumably due to a paraneoplastic vasculitis, known in the literature as granulomatous angiitis [9]. The appearance of Hodgkin's lymphoma and granulomatous angiitis of the CNS was first described in 1972 by Greco et al. [14]. They described the clinical course and complete remission after adequate chemotherapy. Furthermore, the authors suggested a possible association with varicella-zoster virus and the appearance of granulomatous angiitis in Hodgkin's lymphoma. Paraneoplastic angiitis is extremely rare in Hodgkin's lymphoma patients but has been described in a small series with poor outcome [9]. Rapid onset of therapy is necessary to avoid neurological complications including venous thrombosis or stroke [15]. Therapy of choice is steroids 


\begin{tabular}{r|l|l|l}
$\begin{array}{r}\text { Case Reports in } \\
\text { Oncology }\end{array}$ & $\begin{array}{l}\text { Case Rep Oncol 2011;4:106-114 } \\
\text { DOl: 10.1159/000324922 }\end{array}$ & $\begin{array}{l}\text { Published online: } \\
\text { February 25, 2011 }\end{array}$ & $\begin{array}{l}\text { O 2011 S. Karger AG, Basel } \\
\text { ISSN 1662-6575 } \\
\text { www.karger.com/cro }\end{array}$ \\
\hline
\end{tabular}

and immediate lymphoma-directed chemotherapy. Long-term steroid therapy seems to be necessary in some patients to avoid recurrence of neurological symptoms [16].

In our patient, direct involvement of the CNS by Hodgkin's lymphoma seems highly unlikely since normal liquor cytology was demonstrated and the patient is in continuous remission 5 months after diagnosis. It has to be stressed, however, that liquor cytology is not sensitive and specific enough to establish or rule out the diagnosis of direct CNS involvement of Hodgkin's lymphoma. Gerstner et al. [4] analyzed a series of 16 cases of CNS Hodgkin's lymphoma, and 9 of these 16 patients had lumbar puncture but only 2 patients had atypical cells in liquor and just 1 had CD30 positive cells. On the other hand, to our knowledge there is no case of NLPHL documented with direct CNS involvement $[1,4]$.

In conclusion, we present the case of a 25 -year-old patient with new onset epileptic seizures. Further examination demonstrated NLPHL stage II A and MRI showed cerebral vasculitis, most likely granulomatous angiitis. Because of the well-known poor outcome of this condition in the absence of rapid treatment, the patient was immediately treated with steroids and chemotherapy and is now in complete and enduring oncological and neurological remission 5 months after diagnosis. Patients with Hodgkin's lymphoma and neurological symptoms of recent onset require urgent clinical work-up because the differential diagnosis is broad and includes several dangerous conditions. Direct CNS involvement is extremely rare but should be excluded by spinal tap or in unsecure cases by brain biopsy. Additional work-up depends on the clinical presentation, and in patients with ataxia, an anti-Tr antibody-positive PCD needs to be ruled out. Most importantly, treatment should be initiated rapidly in all patients with Hodgkin's lymphoma and neurological symptoms.

\section{Disclosure Statement}

The authors declare that they have no competing interests. 


\begin{tabular}{r|l|l|l}
$\begin{array}{r}\text { Case Reports in } \\
\text { Oncology }\end{array}$ & $\begin{array}{l}\text { Case Rep Oncol 2011;4:106-114 } \\
\text { DOl: 10.1159/000324922 }\end{array}$ & $\begin{array}{l}\text { Published online: } \\
\text { February 25, 2011 }\end{array}$ & $\begin{array}{l}\text { O 2011 S. Karger AG, Basel } \\
\text { ISSN 1662-6575 } \\
\text { www.karger.com/cro }\end{array}$ \\
\hline
\end{tabular}

Table 1. Paraneoplastic events in the nervous system in Hodgkin's lymphoma patients

\begin{tabular}{|c|c|c|c|c|c|c|c|c|c|}
\hline Age & $\begin{array}{l}\text { Gen- } \\
\text { der }\end{array}$ & Diagnosis (symptoms) & $\begin{array}{l}\text { Pathologic findings } \\
\text { MRI, CT scanner }\end{array}$ & CSF & $\mathrm{Lab}$ & Treatment & Stage & Outcome & Reference \\
\hline 23 & $\mathrm{~F}$ & $\begin{array}{l}\text { paraneoplastic } \\
\text { syndrome } \\
\text { (paraparesis, } \\
\text { sphincter dysfunction, } \\
\text { nystagmus) }\end{array}$ & $\begin{array}{l}\text { basal ganglia, } \\
\text { cerebellar tonsil, } \\
\text { internal capsule, } \\
\text { medulla spinae }\end{array}$ & $\begin{array}{l}\text { lymphocytosis, } \\
\text { elevated protein }\end{array}$ & normal & $\begin{array}{l}\text { ABVD, } \\
\text { steroids, IVIG, } \\
\text { plasmapheresis }\end{array}$ & I A & $\begin{array}{l}\text { persistent } \\
\text { paraperesis }\end{array}$ & $\begin{array}{l}\text { Kalinka E. } \\
\text { et al., } 2002 \\
{[17]}\end{array}$ \\
\hline 53 & M & $\begin{array}{l}\text { paraneoplastic } \\
\text { cerebellar ataxia } \\
\text { (gait disturbance, } \\
\text { cerebellar ataxia, } \\
\text { downbeat nystagmus) }\end{array}$ & none & $\begin{array}{l}\text { positive } \\
\text { anti-Tr } \\
\text { antibodies }\end{array}$ & $\begin{array}{l}\text { positive } \\
\text { anti-Tr } \\
\text { antibodies }\end{array}$ & $\begin{array}{l}\text { ABVD, } \\
\text { radiation, IVIG, } \\
\text { steroids, } \\
\text { plasmapheresis }\end{array}$ & n.a. & $\begin{array}{l}\text { neurology } \\
\text { improved } \\
\text { dramatically }\end{array}$ & $\begin{array}{l}\text { Taniguchi Y. } \\
\text { et al., 2006 [6] }\end{array}$ \\
\hline 55 & M & $\begin{array}{l}\text { paraneoplastic angiitis } \\
\text { (transient right } \\
\text { hemiparesis, right } \\
\text { upper limb } \\
\text { ataxic monoparesis) }\end{array}$ & $\begin{array}{l}\text { recurrent cerebral } \\
\text { venous thrombosis }\end{array}$ & $\begin{array}{l}\text { mild } \\
\text { lymphozytosis }\end{array}$ & normal & $\begin{array}{l}\text { rituximab and } \\
\text { steroids }\end{array}$ & I A & $\begin{array}{l}\text { improved } \\
\text { symptoms }\end{array}$ & $\begin{array}{l}\text { Roggerone S. } \\
\text { et al., 2008 } \\
\text { [15] }\end{array}$ \\
\hline 52 & $\mathrm{M}$ & $\begin{array}{l}\text { granulomatous angiitis } \\
\text { (generalized } \\
\text { tonic-clonic } \\
\text { convulsion, confusion) }\end{array}$ & $\begin{array}{l}\text { confluent white } \\
\text { matter change }\end{array}$ & $\begin{array}{l}\text { lymphocytic } \\
\text { pleocytosis, } \\
\text { elevated protein }\end{array}$ & $\begin{array}{l}\text { ESR } \\
21 \mathrm{~mm} / \mathrm{h} \\
\mathrm{CRP} \\
2.8 \mathrm{mg} / \mathrm{l}\end{array}$ & CTX, steroids & III A & $\begin{array}{l}\text { no further } \\
\text { seizures; } \\
\text { confusion } \\
\text { resolved }\end{array}$ & $\begin{array}{l}\text { Sheehy N. } \\
\text { et al., } 2003 \\
{[18]}\end{array}$ \\
\hline 26 & $\mathrm{~F}$ & $\begin{array}{l}\text { granulomatous angiitis } \\
\text { (diplopia, nausea, } \\
\text { emesis, headache, } \\
\text { seizure-like episodes) }\end{array}$ & $\begin{array}{l}\text { areas of increased } \\
\text { signaling in the } \\
\text { parietal and } \\
\text { temporal lobe }\end{array}$ & $\begin{array}{l}\text { lymphocytic } \\
\text { pleocytosis, } \\
\text { elevated protein }\end{array}$ & n.a. & $\begin{array}{l}\text { ABVD, } \\
\text { steroids, RTX }\end{array}$ & I A & $\begin{array}{l}\text { patient } \\
\text { remained } \\
\text { symptom- } \\
\text { free for 2-year } \\
\text { follow-up }\end{array}$ & $\begin{array}{l}\text { Delobel P. } \\
\text { et al., } 2004 \\
{[19]}\end{array}$ \\
\hline
\end{tabular}

ESR = Erythrocyte sedimentation rate; CRP = C-reactive protein; IVIG = intravenous immunoglobulin; CTX = chemotherapy; RTX = radiotherapy; n.a. = not available. 


\begin{tabular}{c|l|l|l}
$\begin{array}{c}\text { Case Reports in } \\
\text { Oncology }\end{array}$ & $\begin{array}{l}\text { Case Rep Oncol 2011;4:106-114 } \\
\text { DOl: 10.1159/000324922 }\end{array}$ & $\begin{array}{l}\text { Published online: } \\
\text { February 25, 2011 }\end{array}$ & $\begin{array}{l}\text { O 2011 S. Karger AG, Basel } \\
\text { ISSN 1662-6575 } \\
\text { www.karger.com/cro }\end{array}$ \\
\hline
\end{tabular}
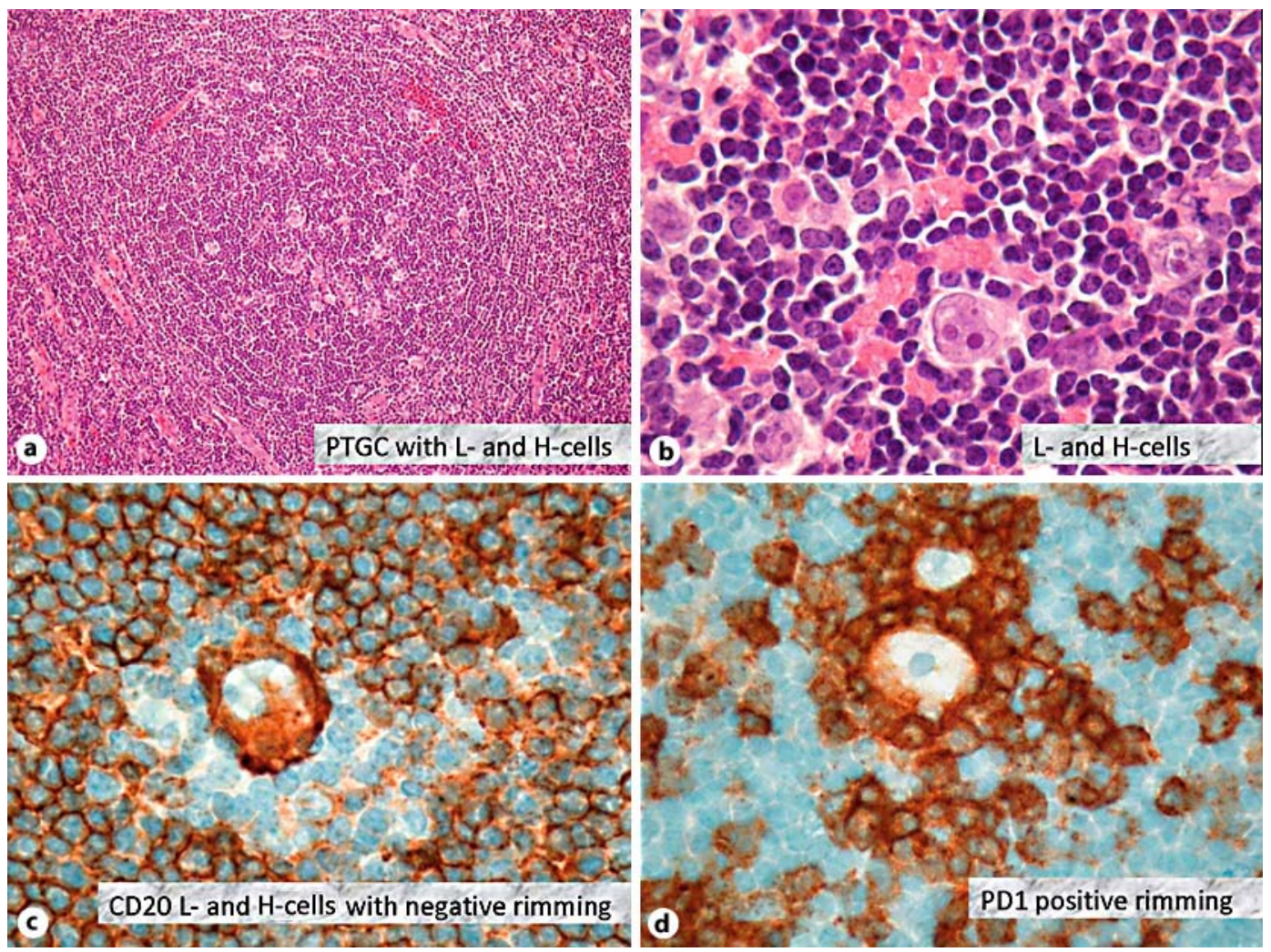

Fig. 1. a Pathologic findings in a cervical lymph node with nodular transformation with detectable typical L- and H-cells. PTGC = Progressive transformation of germinal centers. $\mathbf{b}$ Detailed view of typical L- and H-cells. c CD20 expression by L- and H-cells with negative T-cell rimming. d PD1positive $\mathrm{T}$-cell rimming. These are typical immunohistochemical findings in NLPHL. 


\begin{tabular}{r|l|l|l}
$\begin{array}{c}\text { Case Reports in } \\
\text { Oncology }\end{array}$ & $\begin{array}{l}\text { Case Rep Oncol 2011;4:106-114 } \\
\text { DOl: 10.1159/000324922 }\end{array}$ & $\begin{array}{l}\text { Published online: } \\
\text { February 25, 2011 }\end{array}$ & $\begin{array}{l}\text { O 2011 S. Karger AG, Basel } \\
\text { ISSN 1662-6575 } \\
\text { www.karger.com/cro }\end{array}$ \\
\hline
\end{tabular}

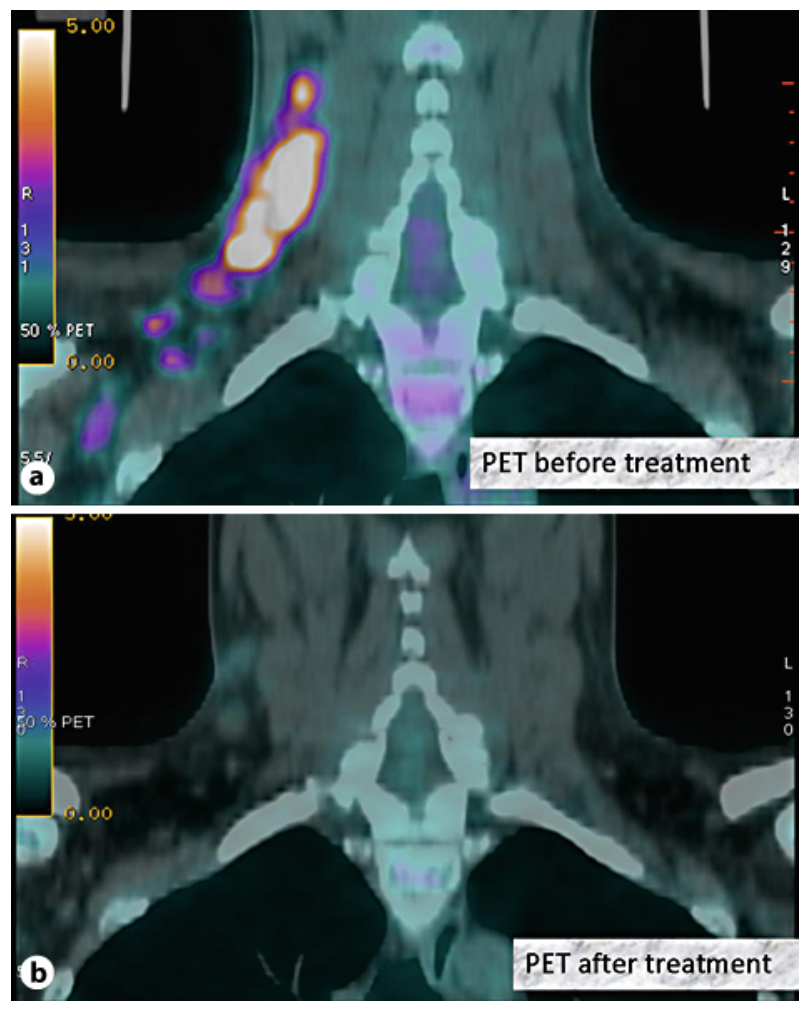

Fig. 2. a PET-CT with pathologically increased glucose metabolism in enlarged cervical lymph nodes. b PET-CT with metabolic remission after 2 cycles of ABVD chemotherapy (adriamycin, bleomycin, vinblastine and dacarabazine). 


\begin{tabular}{c|l|l|l}
$\begin{array}{c}\text { Case Reports in } \\
\text { Oncology }\end{array}$ & $\begin{array}{l}\text { Case Rep Oncol 2011;4:106-114 } \\
\text { DOI: 10.1159/000324922 }\end{array}$ & $\begin{array}{l}\text { Published online: } \\
\text { February 25, 2011 }\end{array}$ & $\begin{array}{l}\text { O 2011 S. Karger AG, Basel } \\
\text { ISSN 1662-6575 } \\
\text { www.karger.com/cro }\end{array}$ \\
\hline
\end{tabular}

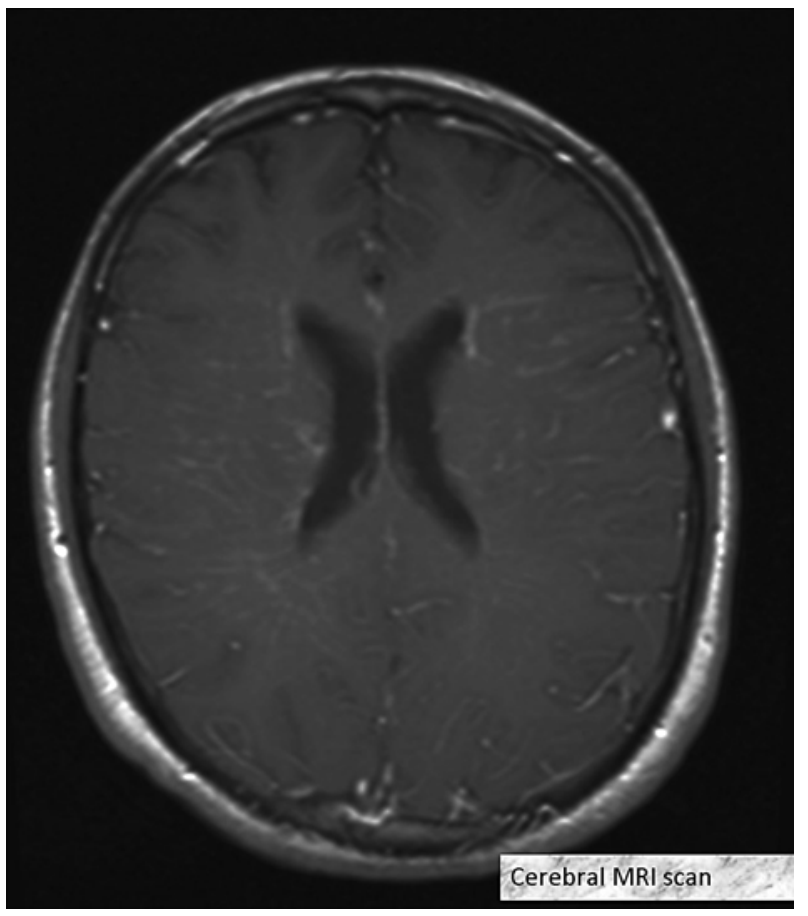

Fig. 3. Cerebral MRI scan with pathologic infiltration due to vasculitic change in both temporal lobes.

\section{References}

1 Re D, Fuchs M, Schober T, Engert A, Diehl V: CNS involvement in Hodgkin’s lymphoma. J Clin Oncol 2007;25:3182.

-2 Anselmo AP, Proia A, Cartoni C, Baroni CD, Maurizi Enrici R, Delfini R, Avvisati G: Meningeal localization in a patient with Hodgkin's disease: description of a case and review of the literature. Ann Oncol 1996;7:10711075.

3 Sachdeva MU, Suri V, Malhotra P, Srinivasan R: Cerebrospinal fluid infiltration in Hodgkin lymphoma: a case report. Acta Cytol 2008;52:623-626.

4 Gerstner ER, Abrey LE, Schiff D, Ferreri AJ, Lister A, Montoto S, Tsang R, Thiel E, Graus F, Behringer D, Illerhaus G, Weaver S, Wen P, Voloschin A, Harris NL, Batchelor TT: CNS Hodgkin lymphoma. Blood 2008;112:1658-1661.

5 Almhanna K, Wongchaowart N, Sweetenham J: Intracerebral Hodgkin's lymphoma in a patient with chronic lymphocytic leukemia/small lymphocytic lymphoma: a case report and literature review. Cancer Invest 2009;27:215-220.

6 Taniguchi Y, Tanji C, Kawai T, Saito H, Marubayashi S, Yorioka N: A case report of plasmapheresis in paraneoplastic cerebellar ataxia associated with anti-Tr antibody. Ther Apher Dial 2006;10:90-93.

7 Hammack J, Kotamides H, Rosenblum MK, Posner JB: Paraneoplastic cerebellar degeneration. II. Clinical and immunologic findings in 21 patients with Hodgkin's disease. Neurology 1992;42:1938-1942.

8 Reich H: Allergic granulomatous angiitis. Arch Klin Exp Dermatol 1957;206:229-230.

-9 Rosen CL, De Palma L, Morita A: Primary angiitis of the central nervous system as a first presentation in Hodgkin's disease: a case report and review of the literature. Neurosurgery 2000;46:1504-1508, discussion 1508-1510.

10 Julien J, Vital C, Aupy G, Lagueny A, Darriet D, Brechenmacher C: Guillain-Barré syndrome and Hodgkin's disease - ultrastructural study of a peripheral nerve. J Neurol Sci 1980;45:23-27.

11 Lucchinetti CF, Kimmel DW, Lennon VA: Paraneoplastic and oncologic profiles of patients seropositive for type 1 antineuronal nuclear autoantibodies. Neurology 1998;50:652-657. 
12 Ferrò MT, Riccardi T, Montanelli A, Bernasconi P, Mantegazza R: Myasthenia gravis remission and anti-AChR $\mathrm{ab}$ reduction after immunosuppressive and anti-neoplastic therapy in a patient with thymic Hodgkin's disease. J Neurol 2006;253:1241-1242. J Neurol 2006;253:1241-1242.

$\checkmark 13$ To KW, Thirkill CE, Jakobiec FA, Lessell S, Berson EL: Lymphoma-associated retinopathy. Ophthalmology 2002;109:2149-2153.

14 Greco FA, Kolins J, Rajjoub RK, Brereton HD: Hodgkin's disease and granulomatous angiitis of the central nervous system. Cancer 1976;38:2027-2032.

15 Roggerone S, Traverse-Glehen A, Derex L, Honnorat J, Berger F, Salles G, Rousset H, Trouillas P, Nighoghossian N: Recurrent cerebral venous thrombosis revealing paraneoplastic angiitis in Hodgkin's lymphoma. J Neurooncol 2008;89:195-198.

-16 Power DG, Mullholland PJ, Sheehy N, Farrell MA, Daly PA: Relapsing granulomatous angiitis of the central nervous system in a patient while in remission from Hodgkin lymphoma. Ir Med J 2006;99:282.

17 Kalinka E, Robak T, Wrzesien-Kus A, Krykowski E, Warzocha K: Diagnostic and therapeutic quandaries in primary manifestation of Hodgkin's disease in the central nervous system. Ann Hematol 2002;81:289-291.

18 Sheehy N, Sheehan K, Brett F, Kay E, Grogan L, Delanty N: Hodgkins disease presenting with granulomatous angiitis of the central nervous system. J Neurol 2003;250:112-113.

19 Delobel P, Brassat D, Danjoux M, Lotterie JA, Irsutti-Fjørtoft M, Clanet M, Laurent G: Granulomatous angiitis of the central nervous system revealing Hodgkin's disease. J Neurol 2004;251:611-612. 